\title{
Evaluation of the phenyl-bonded silica-based sorbent for pre- concentration of the booster antifouling biocides Zinc Pyrithione, Zineb and Ziram using solid-phase extraction technique and Inductively Coupled Plasma Mass Spectrometry
}

Ana Marta Cavinato Marchini Rolisola ${ }^{1+(10}$, Amauri Antônio Menegário1(i), Lauren Nozomi Marques Yabukie Luciana Polese $^{1}\left[\right.$, , Chang Hung Kiang ${ }^{1}$ ()

1. São Paulo State University (Unesp), Enviromental Studies Center, Rio Claro, São Paulo, Brazil

2. São Paulo State University (Unesp), Institute of Geosciences and Exact Sciences, Rio Claro, São Paulo, Brazil

${ }^{+}$Corresponding author: Ana Marta Cavinato Marchini Rolisola, Phone: +55 19 3526-9491, Email address: anamartarolisola@hotmail.com

\section{ARTICLE INFO}

Article history:

Received: October 22, 2019

Accepted: March 30, 2020

Published: October 01, 2020

\author{
Keywords: \\ 1. antifouling \\ 2. zinc pyrithione \\ 3. zineb \\ 4. ziram \\ 5. solid-phase extraction
}

\begin{abstract}
A robust method of solid-phase extraction technique with use of the phenylbonded silica-based sorbent ( $\mathrm{Si}-\mathrm{PH}$ sorbent) for pre-concentration of three booster antifouling biocides: zinc pyrithione, Zineb and Ziram in ultrapure water fortified and estuarine water sample was evaluated for zinc determination by collision cell technology-inductively coupled plasma-mass spectrometry (CCT-ICP-MS). Decontamination process to remove metals and prevent (trans-) metallization of the Si-PH sorbent with $20 \mathrm{~mL}$ of nitric acid $0.006 \mathrm{~mol} \mathrm{~L}^{-1}$ was performed. This proposed solid-phase extraction efficiency of three booster antifouling biocides by the phenyl-bonded silica-based sorbent (Si-PH sorbent) was evaluated in $40 \mathrm{~mL}$ of ultrapure water fortified sample $\left(40 \mu \mathrm{g} \mathrm{L}^{-1}\right.$ of the zinc biocides). The adsorption of zinc pyrithione, Zineb

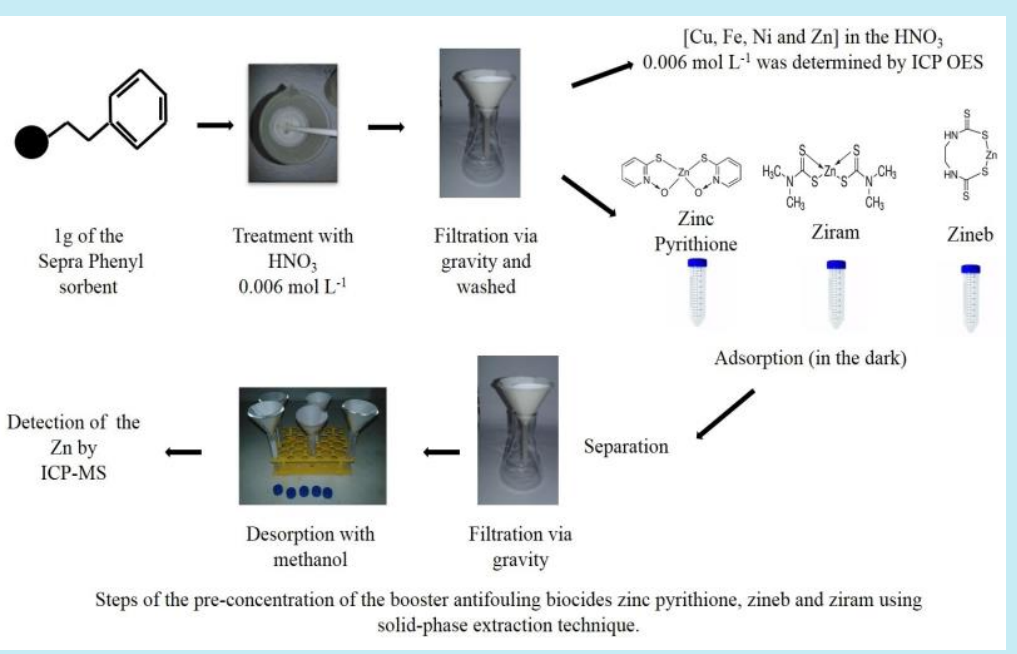
and Ziram were $94.2 \pm 0.1 \%, 85.13 \pm 0.04 \%$ and $93.35 \pm 0.09 \%$, respectively. The limit of detection and limit of quantification values obtained were $0.66 \mu \mathrm{g} \mathrm{L}^{-1}$ and $2.19 \mu \mathrm{g} \mathrm{\textrm {L } ^ { - 1 }}$, respectively. Good recoveries of zinc pyrithione $(85 \pm 2 \%)$, Zineb $(89 \pm 5 \%)$ and Ziram $(111 \pm 2 \%)$ in the elution step for booster antifouling biocides from the fortified estuarine water were obtained.
\end{abstract}

\section{Introduction}

The contamination of the marine environment by metals is mainly due to impact of anthropic activities. In areas where the nautical activity is intense, such as ports, marinas and docks, risk of contamination is significant due to circulation of ships and boats. To avoid biological fouling, ships and vessels treat the hull with antifouling paint. Consequently, application of antifouling paints helps to prevent the settlement and growth of algae, mussels, and other marine organisms in the hulls of vessels and small ship. However, antifouling particles are released into the seawater gradually from these antifouling paints that were applied on the hulls of vessels and small ship representing risk to marine organisms. In 2001, International Maritime Organization (IMO) prohibited tributyltin (TBT) in antifouling paints applied on ships ${ }^{1}$. So, a new generation of booster antifouling biocides has been used: chlorothalonil, dichlofluanid, Irgarol 1051, TCMS pyridine, 
thiocyanatomethylthio-benzothiazole (TCMTB), diuron, dichloro-octylisothiazolin (DCOIT, Sea Nine 211), zinc and copper pyrithione (zinc and copper omadine), Zineb (zinc ethylenebisdithiocarbamate) and Ziram (zinc dimethyldithiocarbamate) ${ }^{2-4}$. Recently, there is a considerable increase in the use of zinc pyrithione $\left(\mathrm{Zn}(\mathrm{PT})_{2}\right)$ and copper pyrithione $\left(\mathrm{Cu}(\mathrm{PT})_{2}\right)$, in freshwater and seawater booster antifouling biocides, because their antimicrobial and antifungal activity is highly effective ${ }^{5}$.

The effects and toxicity of booster antifouling biocides on different species of fish, crustaceans, invertebrates, and algae were studied ${ }^{6}$. Studies with sea urchin eggs and embryos demonstrated that $\mathrm{Zn}(\mathrm{PT})_{2}\left(0.01 \mathrm{fg} \mathrm{L}^{-1}\right)$ is more toxic than $\mathrm{Cu}(\mathrm{PT})_{2}\left(1,000 \mathrm{fg} \mathrm{L}^{-1}\right)^{7}$. The $\mathrm{Zn}(\mathrm{PT})_{2}$ showed similar toxicity to TBT for ascidian Botryllus schlosseri cultured hemocytes in extremely low concentrations $31.7 \mu \mathrm{g} \mathrm{\textrm {L } ^ { - 1 }}$ and $158 \mu \mathrm{g} \mathrm{\textrm {L } ^ { - 1 }}$, respectively ${ }^{8}$. The sublethal exposure of musselsin the 14-day period to $\mathrm{Zn}(\mathrm{PT})_{2}\left(0.2\right.$ or $\left.2 \mathrm{mmol} \mathrm{L}^{-1}\right)$, along with inorganic $\mathrm{Zn}$ and seawater controls) was considered genotoxic for mussel haemocytes 9 . The authors showed in the acute toxicity study of $\mathrm{Zn}(\mathrm{PT})_{2}$ in fish Carassius $s p$. that the concentration required to kill half the members of a tested population after a specified test duration - $96 \mathrm{~h}$ (Lethal Concentration 50\% LC50 96 h) of $\mathrm{Zn}(\mathrm{PT})_{2}$ in Carassius sp. cultivated in freshwater or water with 1.5 or $3 \%$ salinity was $0.163,0.126$ and $0.113 \mathrm{mg} \mathrm{L}^{-1}$, respectively ${ }^{10}$. Acute toxicity of booster antifouling biocides was determined for phytoplankton Nitzschia pungens and zooplankton Artemia larvae showed a half maximal effective concentration (EC50 $96 \mathrm{~h}$ ) for Zineb $\left(232 \mu \mathrm{g} \mathrm{L}^{-1}\right), \mathrm{Zn}(\mathrm{PT})_{2}\left(5.5 \mu \mathrm{g} \mathrm{L}^{-1}\right)$, Ziram $\left(\begin{array}{llllll}5.4 & \mu \mathrm{g} & \mathrm{L}^{-1}\end{array}\right), \quad \mathrm{Cu}(\mathrm{PT})_{2} \quad\left(4.9 \mu \mathrm{g} \quad \mathrm{L}^{-1}\right) \quad$ in phytoplankton Nitzschia pungens. In zooplankton Artemia larvae, the booster antifouling biocides present LC50 (48 h, for larval survivals) for Zineb (41 $\mathrm{mg} \mathrm{L} \mathrm{L}^{-1}$ ), Ziram (4.8 $\left.\mathrm{mg} \mathrm{L}^{-1}\right), \quad \mathrm{Zn}(\mathrm{PT})_{2}$ (3.2 $\left.\mathrm{mg} \mathrm{L}^{-1}\right)$ and $\mathrm{Cu}(\mathrm{PT})_{2}\left(0.3 \mathrm{mg} \mathrm{L}^{-1}\right)^{11}$.

The development of analytical methods to determine environmental concentrations of these booster antifouling biocides (e.g. zinc pyrithione $\mathrm{Zn}(\mathrm{PT})_{2}$, Zineb and Ziram) in complex matrices (e.g. estuarine water and seawater samples) is of great relevance due to the mechanisms of the oxidation and (trans-) metallization that currently complicate chromatographic analysis and other studies $^{12}$. For the quantification of trace level analytes $\left(\mu \mathrm{g} \mathrm{L}^{-1}\right.$ or $\left.n g \mathrm{~L}^{-1}\right)$ in complex matrices, it is necessary to use a sample preparation step. This step aims for the pre-concentration of analytes and the removal of interferents ${ }^{13-15}$. Solid-Phase Extraction (SPE) has a great potential to provide proper pre-concentration for ultra-trace analysis of booster antifouling biocides. In addition, SPE avoids coelution of the matrix interferents along with the compounds of interest when High Performance Liquid Chromatography (HPLC) is used and an important advantage of SPE is the possibility of extracting a wide range of analytes (from non-polar to very polar analytes) from a wide variety of samples ${ }^{16}$. SPE as an aqueous sample preparation step should consider the characteristics of the sorbent, matrix solvents used in the conditioning and elution steps, analyte of interest and detector used to quantify the analyte.

Several methods have been used to preconcentrate the booster antifouling biocides by using, pre-column cartridge ${ }^{17,18}$, adsorbent column $^{19}$ commercial cartridges ${ }^{20,21}$, extraction disks $^{22}$ and $\mathrm{C} 18$-functionalized paramagnetic nanoparticles ${ }^{23}$. Different hyphenated instrumental methods have been used to determinate the booster antifouling biocides over the years, e.g. HPLC coupled with: i) Ultraviolet-Visible $(\mathrm{UV}-\mathrm{VIS})^{10,12,17,20,23-26}$, ii) Diode-Array (DAD) ${ }^{12}$, iii) Electrospray Ionization Mass Spectrometry $(\text { ESI-MS })^{12}$, iv) Atmospheric Pressure Chemical Ionization Mass Spectrometry (APCI-MS) ${ }^{18,25}$, v) Tandem-Mass Spectrometry (MS/MS $)^{26,27}$, vi) Atomic Absorption Spectrometry ${ }^{28}$, vii) fluorescence ${ }^{29}$.

Specifically, for Ziram and Zineb, the amount of zinc present in booster antifouling biocide was determined by Flame Atomic Absorption Spectrometry (Flame-AAS) and spectrophotometry after separation using HPLC $^{30}$ and for residue analysis of Zineb 68\% + Hexaconazole $4 \%$ mixture was used Gas Chromatography Coupled with Triple Quadrupole Mass Spectrometry (GC-MS/MS) ${ }^{31}$.

The aim of this work was to evaluate the phenyl-bonded silica-based sorbent (Sepra Phenyl, Phenomenex) for pre-concentration booster antifouling biocides zinc pyrithione, Zineb and Ziram from the estuarine water sample using SPE technique. For the first time this sorbent was used to pre-concentrate the zinc-based booster antifouling biocides zinc pyrithione, Zineb and Ziram from the ultrapure water fortified sample $\left(40 \mu \mathrm{g} \mathrm{L}^{-1}\right)$ and estuarine water sample with metal removal to prevent (trans-) metallization. 


\section{Experimental}

\subsection{Materials and reagents}

The booster antifouling biocides zinc pyrithione (purity $\geq 95 \%$, CAS 13463-41-7), Zineb Pestanal ${ }^{\circledR}$ (purity 97\%, CAS 12122-67-7) and Ziram Pestanal ${ }^{\circledR}$ (purity 97\%, CAS 137-30-4) were obtained from Sigma-Aldrich (Brazil). Dimethylsulfoxide (DMSO) was supplied by LABSYNTH (Brazil); HPLC grade methanol $(\mathrm{MeOH})$ was purchased from Panreac (Spain); nitric acid $\left(\mathrm{HNO}_{3}\right)$ was obtained from Merck (Germany); resin Chelex ${ }^{\circledR}-100$ (Na form, 100-200 wet mesh) was supplied by Bio-Rad (Canada). The Sepra Phenyl Sorbent (endcapped silicabased phenyl, $50 \mu \mathrm{m}, 65 \AA, \leq 10 \mathrm{kDa}$ ) were obtained from Phenomenex (USA) and commonly applied to reversed phase, hydrophobic and aromatic, small molecule selectivity from aqueous samples. Quantitative filter paper C42 blue strip, diameter $12.5 \mathrm{~cm}$ was supplied Unifil (Germany) and $0.22 \mu \mathrm{m}$ nylon filter (disk) Allcrom (Brazil).

Ultrapure water (18 $\mathrm{M} \Omega \mathrm{cm}$ resistivity) obtained with a Millipore system (Millipore,
Bedford, MA) was used exclusively. The stock solutions of $200 \mathrm{mg} \mathrm{L}^{-1}$ each booster antifouling biocide $\left(\mathrm{Zn}(\mathrm{PT})_{2}\right.$, Zineb and Ziram) was prepared in DMSO monthly and stored in the refrigerator at $4{ }^{\circ} \mathrm{C}$ (in dark).

\subsection{Instrumentation}

The Inductively Coupled Plasma Optical Emission Spectrometer (ICP OES) model iCAP 6000 Series (Thermo Scientific, Germany) was used to determine the higher concentrations of zinc and other metals presented in solution of $\mathrm{HNO}_{3} 0.006 \mathrm{~mol} \mathrm{~L}^{-1}$ and $1.6 \mathrm{~mol} \mathrm{~L}^{-1}$ used in decontamination processes. An Inductively Coupled Plasma Mass Spectrometry (ICP-MS) model X Series II (Thermo Scientific, Germany) was used to zinc determination in the ultrapure water fortified sample, estuarine water sample of the Santos/SP Estuary (Brazil) and methanol of the elution step. Tab. 1 reports the instrumental and analytical parameters. The instrument was optimized before each reading with a $10 \mathrm{ng} \mathrm{mL}^{-1}$ standard tune solution (Ba, Be, Bi, Ce, Co, In, Li, $\mathrm{Ni}, \mathrm{Pb}$ and $\mathrm{U})$.

Table 1. Instrumental and Analytical Parameters of ICP-MS.

\begin{tabular}{|l|l|}
\hline \multicolumn{1}{|c|}{ Parameter } & \multicolumn{1}{c|}{ Configuration Used } \\
\hline RF power & Mira Mist ${ }^{\circledR}$ \\
\hline Nebulizer & Glass Conical Impact Bead \\
\hline Spray chamber & $1-$ Piece, $1.5 \mathrm{~mm}$ injector diameter \\
\hline Torch & Ni sampler and skimmer \\
\hline Interface Cones & $1 \mathrm{~mL} \mathrm{~min}^{-1}$, approx., pumped \\
\hline Sample uptake rate & Standard resolution mode: peak width 0.70 amu at \\
\hline Quadrupole resolution & $5 \%$ height \\
\hline Nebulizer gas & $0.75 \mathrm{~L} \mathrm{~min}^{-1}$ \\
\hline Plasma gas & $13 \mathrm{~L} \mathrm{~min}{ }^{-1}$ \\
\hline Auxiliary gas & $0.7 \mathrm{~L} \mathrm{~min}^{-1}$ \\
\hline Monitored mass & $\mathrm{Zn} \mathrm{m/z} 64$ \\
\hline Dwell time & $10 \mathrm{~ms}^{-1}$ \\
\hline CCT gas (He 5.0 - analytical) & $8.3 \mathrm{~mL} \mathrm{~min}^{-1}$ \\
\hline Acquisition mode & Peak jumping \\
\hline Internal Standard Isotopes & ${ }^{45} \mathrm{Sc} \mathrm{and}{ }^{89} \mathrm{Y}$ \\
\hline
\end{tabular}

\subsection{Decontamination processes}

\subsubsection{Glassware and plastic materials,} quantitative filter paper and $0.22 \mu \mathrm{m}$ nylon filter

All glassware and plastic materials were submerged in $\mathrm{HNO}_{3} 3.2 \mathrm{~mol} \mathrm{~L}^{-1}$ for $4 \mathrm{~h}$, rinsed with ultrapure water and posteriorly, dried in laminar flow hood. The quantitative filter paper (used in the gravity filtration of $\mathrm{Si}-\mathrm{PH}$ sorbent) and $0.22 \mu \mathrm{m}$ nylon filters (used in vacuum filtration of $\mathrm{MeOH}$ ) was decontaminated by placing in $\mathrm{HNO}_{3} 1.6 \mathrm{~mol} \mathrm{~L}-1$ for $4 \mathrm{~h}$. Then they were washed with ultrapure water until $\mathrm{pH}=6.0$ and dried in a laminar flow hood.

The decontamination process on the glass or 
plastic materials, the quantitative filter paper, $0.22 \mu \mathrm{m}$ nylon filter and the Si-PH sorbent was performed for $\mathrm{Zn}$ removal (possibly presented in these materials with overestimation risk of the real $\mathrm{Zn}$ concentration in estuarine water samples). Further $\mathrm{Zn}$, the metal removal $(\mathrm{Cr}, \mathrm{Cu}, \mathrm{Fe}$ and $\mathrm{Ni}$, for example) was also performed to avoid the possible (trans-) metallization of these metals with the zinc-based antifouling biocides ${ }^{12}$. Therefore, chromium, copper, iron, nickel and zinc concentrations present in $\mathrm{HNO}_{3}$ used for decontamination were determined by ICP OES. This determination was performed by ICP OES due to the possbile presence of these metals in higher concentrations, without a requirement for the detection technique with a higher sensibility as ICP-MS.

\subsubsection{Zinc removal in methanol with Chelex ${ }^{\circledR}-100$ resin}

The zinc amount in the treated and not treated $\mathrm{MeOH}$ with Chelex $^{\circledR}$-100 resin (200-400 mesh, sodium form) was evaluated. For the treated $\mathrm{MeOH}, 0.1 \mathrm{~g}$ of Chelex ${ }^{\circledR}-100$ resin was added in $25 \mathrm{~mL}$ of $\mathrm{MeOH}$. This mixture remained for 10 min under constant stirring and $10 \mathrm{~min}$ at rest. The zinc amount was determined by ICP-MS from $10 \mathrm{~mL}$ of a $\mathrm{MeOH}$ solution $5 \%\left(\mathrm{v} \mathrm{v}^{-1}\right)$ treated with the Chelex ${ }^{\circledR}-100$ resin and another $\mathrm{MeOH}$ solution $5 \%\left(\mathrm{v} \mathrm{v}^{-1}\right)$ not treated with the Chelex ${ }^{\circledR}-100$ resin. Posteriorly, for the $\mathrm{Zn}$ removal present in the $\mathrm{MeOH}$ (used in extraction of the booster antifouling biocides), $2.0 \mathrm{~g}$ of Chelex ${ }^{\circledR}-100$ resin were placed in $500 \mathrm{~mL}$ of $\mathrm{MeOH}$ under constant stirring for $10 \mathrm{~min}$ followed by $10 \mathrm{~min}$ at rest. Then the $\mathrm{MeOH}$ was vacuum filtered using $0.22 \mu \mathrm{m}$ nylon filter decontaminated and stored in a $500 \mathrm{~mL}$ glass bottle.

\subsubsection{Removal of the metals present in phenyl- bonded silica based sorbent}

To metal removal of the Si-PH sorbent, $1.0 \mathrm{~g}$ of the Si-PH sorbent in $20 \mathrm{~mL}$ of $\mathrm{HNO}_{3} 0.006 \mathrm{~mol}$ $\mathrm{L}^{-1}$ was placed under constant stirring for $20 \mathrm{~min}$. The Si-PH sorbent was then filtered using the gravity filtration technique and washed with $150 \mathrm{~mL}$ of ultrapure water until reach $\mathrm{pH}=6.0$. The chromium, copper, iron, nickel and zinc present in $\mathrm{HNO}_{3} 0.006 \mathrm{~mol} \mathrm{~L}^{-1}$ solution were determined by ICP OES.
2.4 Adsorption and recovery of $\mathrm{Zn}(P T)_{2}$, Zineb and Ziram by the Si-PH sorbent in the ultrapure water fortified sample

In order to evaluate the adsorption and elution of $\mathrm{Zn}(\mathrm{PT})_{2}$, Zineb and Ziram by the Si-PH sorbent, tests were firstly performed with ultrapure water fortified sample. Since no data of booster antifouling biocides was available for the study area and to prevent possible analyte losses in the experiment, the accuracy of the developed method was carried out at a higher level of fortification $\left(40 \mu \mathrm{g} \mathrm{L}^{-1}\right)$. Using three falcon tubes, $50 \mathrm{~mL}$ of the ultrapure water was placed in each tube and was added $\mathrm{Zn}(\mathrm{PT})_{2}$ in the first tube, Zineb in the second tube and Ziram in the third tube for final concentration of $40 \mu \mathrm{g} \mathrm{L} \mathrm{L}^{-1}$ of the each biocide $\left(\mathrm{pH}=6.5\right.$ and $\left.\mathrm{T}=21.5{ }^{\circ} \mathrm{C}\right)$. This procedure was performed in triplicate for each booster antifouling biocide.

A $10 \mathrm{~mL}$ aliquot of the solution was withdrawn before and after the experiment with $\mathrm{Si}-\mathrm{PH}$ sorbent. Determination of zinc in each solution containing $\mathrm{Zn}(\mathrm{PT})_{2}$, Zineb and Ziram by ICP-MS was performed using $10 \mathrm{~mL}$ of each solution and acidified with $\mathrm{HNO}_{3} 3.2 \mathrm{~mol} \mathrm{~L}-1(1.2 \mathrm{~mL})$ and added ultrapure water $(0.8 \mathrm{~mL})$ to a final concentration of $\mathrm{HNO}_{3} 0.32 \mathrm{~mol} \mathrm{~L}$. This test was performed in duplicate for each booster antifouling biocide.

The conditioning and equilibration step was performed using $1 \mathrm{~g}$ of decontaminated $\mathrm{Si}-\mathrm{PH}$ sorbent. To condition and equilibrate the Si-PH sorbent the gravity filtration technique was used and $10 \mathrm{~mL}$ of methanol and $10 \mathrm{~mL}$ of ultrapure water were added, respectively. A mass equal $1 \mathrm{~g}$ of Si-PH sorbent (conditioned and equilibrated) was transferred to a falcon tube containing $40 \mathrm{~mL}$ of $\mathrm{Zn}(\mathrm{PT})_{2}$, Zineb and Ziram solution $\left(40 \mu \mathrm{g} \mathrm{L}^{-1}\right)$. The falcon tube containing the solution and $\mathrm{Si}-\mathrm{PH}$ sorbent was kept under constant stirring for $1 \mathrm{~h}$ in the dark to prevent photodegradation. After stirring, the falcon tube was remained at rest for $10 \mathrm{~min}$ to decant the $\mathrm{Si}-\mathrm{PH}$ sorbent before removing the final aliquot. Zinc determination by ICP-MS in the initial and final aliquots allowed to calculate the adsorbed zinc mass and adsorption percentage of the $\mathrm{Zn}(\mathrm{PT})_{2}$, Zineb and Ziram booster antifouling biocides in $1 \mathrm{~g}$ of $\mathrm{Si}-\mathrm{PH}$ sorbent. The adsorbed zinc mass was calculated by the concentration obtained by ICP-MS multiplied by the dilution factor (1.2) and the volume of the solution (40). The percentage $(\%)$ 
of adsorption was calculated using the values of initial concentration $\left(\mathrm{C}_{\mathrm{i}}\right)$ and final concentration $\left(\mathrm{C}_{\mathrm{f}}\right)$ of the solution by means of Eq. 1 :

$\%$ Adsorption $=\left(C_{i}-C_{f} / C_{i}\right) \times 100$.

\subsection{Adsorption and recovery of $\mathrm{Zn}(P T)_{2}$, Zineb} and Ziram by the Si-PH sorbent in the water sample of the Santos/SP Estuary (Brazil)

The estuarine water sample was collected in the Estuary of Santos/SP (Brazil) downstream at latitude S22 51 ' $30^{\prime \prime}$ and longitude W46 $18^{\prime} 29^{\prime \prime}$. A $6 \mathrm{~L}$ plastic bottle of mineral water was washed three times with ultrapure water and three times with the estuarine water. The non-filterable water sample was not acid preserved but the following experiments were performed at maximum 14 days after the sampling (as preconized EPA SW-846 recommendations) $)^{32}$.

To evaluate the adsorption and recovery of the booster antifouling biocides by the Si-PH sorbent using water sample of the Santos Estuary/SP, $500 \mathrm{~mL}$ of the estuarine water was removed from the refrigerator one day prior to the experiment, transferred to a beaker and held at room temperature to decant the sediment.

In order to determine the zinc concentrations in the estuarine water sample prior to fortification with booster antifouling biocides $\mathrm{Zn}(\mathrm{PT})_{2}$, Zineb and Ziram, the analysis were performed by Collision Cell Technology (CCT)-ICP-MS. The collision cell technology (CCT) features a cell introduced before the mass analyzer which was used in ICP-MS to provide an effective elimination of spectral interferences mainly, polyatomic interferences (i.e. ${ }^{36} \mathrm{Ar}^{14} \mathrm{~N}_{2}$ ).

Using three falcon tubes, $50 \mathrm{~mL}$ of the estuarine water was placed in each tube and the sample was added $\mathrm{Zn}(\mathrm{PT})_{2}$ in the first tube, Zineb in the second tube and Ziram in the third tube for final concentration of the $100 \mu \mathrm{g} \mathrm{L}^{-1}(\mathrm{pH}=7.8$ and $\mathrm{T}=21.5^{\circ} \mathrm{C}$ ). This procedure was performed in triplicate for each booster antifouling biocide.

Before adding the Si-PH sorbent and after end experiment, a $10 \mathrm{~mL}$ aliquot of the fortified estuarine water sample was removed. Determination of zinc in each sample containing $\mathrm{Zn}(\mathrm{PT})_{2}$, Zineb and Ziram by CCT-ICP-MS was performed using only $0.5 \mathrm{~mL}$ of each solution and acidified with $\mathrm{HNO}_{3} 3.2 \mathrm{~mol} \mathrm{~L}-1$ (1 mL) and added ultrapure water $(8.5 \mathrm{~mL})$ to a final concentration of $\mathrm{HNO}_{3} 0.32 \mathrm{~mol} \mathrm{~L}-1$.
A mass equal $1 \mathrm{~g}$ of decontaminated, conditioned and equilibrated Si-PH sorbent was transferred to each falcon tube containing $40 \mathrm{~mL}$ of $\mathrm{Zn}(\mathrm{PT})_{2}$, Zineb and Ziram. The falcon tube containing fortified estuarine water sample and the Si-PH sorbent was under constant stirring for $1 \mathrm{~h}$ in the dark to prevent photodegradation.

After stirring, the falcon tube was held to decant the Si-PH sorbent before removing the final aliquot. Determination of zinc by CCT-ICP-MS in the initial and final aliquots allowed the calculation of the adsorbed zinc mass and the percentage adsorption of the $\mathrm{Zn}(\mathrm{PT})_{2}$, Zineb and Ziram biocides in $1 \mathrm{~g}$ of $\mathrm{Si}-\mathrm{PH}$ sorbent in the estuarine water sample. The adsorbed zinc mass was calculated by the concentration obtained by ICP-MS multiplied by the dilution factor (20) and the volume of the solution (40).

Then, gravity filtration of the remainder of the sample (estuarine water and $\mathrm{Si}-\mathrm{PH}$ sorbent) was performed on the falcon tube. The Si-PH sorbent that remained on the filter paper was washed with $5 \mathrm{~mL}$ of ultrapure water and transferred to another decontaminated quantitative filter paper. The sorbent transfer to another filter paper was performed to avoid that residues of the booster antifouling biocides that were not adsorbed by the sorbent and remained on the filter paper were eluted and consequently would overestimate the recovery values.

Initially, $1 \mathrm{~mL}$ of $100 \% \mathrm{MeOH}\left(\mathrm{v} \mathrm{v}^{-1}\right)$ to elute the $\mathrm{Zn}(\mathrm{PT})_{2}$, Zineb and Ziram from the Si-PH sorbent was used. However, this volume was not enough to cover the mass of $1 \mathrm{~g}$ of Si-PH. So, 5 aliquots of $1 \mathrm{~mL}$ (total $=5 \mathrm{~mL}$ ) of $100 \% \mathrm{MeOH}$ $\left(\mathrm{v} \mathrm{v}^{-1}\right)$ previously treated with Chelex ${ }^{\circledR}-100$ were added under Si-PH sorbent using the gravity filtration technique with an elution rate of the $2 \mathrm{~mL} \min ^{-1}$.

For the $\mathrm{Zn}$ determination in ICP-MS, $0.5 \mathrm{~mL}$ eluate $\left(\mathrm{MeOH} 100 \% \quad\left(\mathrm{v} \mathrm{v}^{-1}\right)\right)$ each booster antifouling biocide was diluted with $8.5 \mathrm{~mL}$ ultrapure water and acidified with $1 \mathrm{~mL} \mathrm{HNO}_{3}$ $3.2 \mathrm{~mol} \mathrm{~L}^{-1}$. The eluate dilution was 20 -fold, resulting in a final concentration of $5 \%\left(\mathrm{v} \mathrm{v}^{-1}\right)$ for $\mathrm{MeOH}$ and $2 \%\left(\mathrm{v} \mathrm{v}^{-1}\right)$ for $\mathrm{HNO}_{3}$. This dilution was necessary because the introduction of organic solvents in the ICP-MS can cause signal suppression, as the intensity the signal is directly related to the concentration of methanol ${ }^{33}$.

A solution containing $\mathrm{MeOH} 5 \%\left(\mathrm{v} \mathrm{v}^{-1}\right)$ and $\mathrm{HNO}_{3} 2 \%\left(\mathrm{v} \mathrm{v}^{-1}\right)$ was nebulized for 15 minutes to stabilize the plasma before analysis of calibration 
curve and samples. The calibration curve of 0,5 , $10,25,50$ and $75 \mu \mathrm{g} \mathrm{L}^{-1}$ was prepared using the same $\mathrm{MeOH}$ and $\mathrm{HNO}_{3}$ concentrations of the eluate and the stabilization solution.

\subsection{Limit of detection and quantification}

The procedure for determining the limit of detection and quantification of the proposed method was performed in the elution step (triplicate). The limit of detection and quantification of the SPE method developed was calculated by multiplying the standard deviation of zinc obtained in the eluate by 3 and by 10 , respectively.

The limit of detection and quantification of this SPE method proposed was estimated according IUPAC recommendations by multiplying the standard deviation of zinc obtained in the eluate (blanks) by 3 and by 10 , respectively. Subsequently, the zinc concentration obtained in the eluate (blanks) in this experimental procedure was subtracted from the eluent of the biocides in the $\mathrm{Zn}(\mathrm{PT})_{2}$, Zineb and Ziram recovery test by the $\mathrm{Si}-\mathrm{PH}$ sorbent in the water sample from the Santos/SP Estuary ${ }^{34}$.

\section{Results and Discussion}

\subsection{Decontamination processes}

\subsubsection{Removal of zinc present in methanol with Chelex ${ }^{\circledR}-100$ resin}

The $\mathrm{Zn}$ amount present in the not treated $\mathrm{MeOH}$ solution decreases from $18 \pm 1 \mu \mathrm{g} \mathrm{L}^{-1}$ to $3 \pm 0.1 \mu \mathrm{g} \mathrm{L}^{-1}$ compared with the treated $\mathrm{MeOH}$ solution indicating a reduction of approximately
83\%. Therefore, the methanol treated with Chelex ${ }^{\circledR}-100$ resin was used in the SPE method development.

\subsubsection{Removal of the metals present in phenyl- bonded silica based sorbent}

The concentrations of the $\mathrm{Cr}, \mathrm{Cu}, \mathrm{Fe}, \mathrm{Ni}$, and $\mathrm{Zn}$ metals were determined quantitatively in a volume of $20 \mathrm{~mL}$ of $\mathrm{HNO}_{3} 0.006 \mathrm{~mol} \mathrm{~L}^{-1}$ used in the $\mathrm{Si}-\mathrm{PH}$ sorbent decontamination process by and the results are presented in Tab. 2 .

It was observed that $\mathrm{Zn}$ has the highest concentration $\left(174 \pm 1 \mu \mathrm{g} \mathrm{L}^{-1}\right)$ followed by $\mathrm{Fe}$ $\left(28 \pm 1 \mu \mathrm{g} \mathrm{L}^{-1}\right)$ and $\mathrm{Ni}\left(15.9 \pm 0.8 \mu \mathrm{g} \mathrm{L}^{-1}\right)$. The concentrations of $\mathrm{Cu}$ and $\mathrm{Cr}$ metals were below $8 \mu \mathrm{g} \mathrm{L}^{-1}$. Based on these results, it is demonstrated the need of carrying out the $\mathrm{Si}-\mathrm{PH}$ sorbent decontamination process for subsequent use in SPE of the booster antifouling biocides. This is justified by the fact that the booster antifouling biocides have $\mathrm{Zn}$ in their composition and this metal showed the highest concentration in the Si$\mathrm{PH}$ sorbent decontamination process. It should be noted that the decontamination process avoided the (trans-) metallization of the booster antifouling biocides with the other metals present in the $\mathrm{Si}$ $\mathrm{PH}$ sorbent.

The choice of $\mathrm{HNO}_{3}$ concentration 0.006 mol L ${ }^{-1}$ used in the Si-PH sorbent decontamination process was based on the fact that the $\mathrm{Si}-\mathrm{PH}$ sorbent is the silica base and its $\mathrm{pH}$ working range is between 2 and 8 as recommended by the manufacturer ${ }^{35}$. Silica becomes unstable and may contain residual silanols resulting in irreversible adsorption of basic compounds outside this $\mathrm{pH}$ working range ${ }^{36}$.

Table 2. Metal concentrations quantified in the Si-PH decontamination process of by ICP OES (axial view).

\begin{tabular}{|c|c|c|c|c|c|}
\hline Solution & $\begin{array}{c}{[\mathrm{Cr}] /} \\
\mu \mathrm{g} \mathrm{L}^{-1}\end{array}$ & $\begin{array}{c}{[\mathrm{Cu}] /} \\
\mu \mathrm{g} \mathrm{L}^{-1}\end{array}$ & $\begin{array}{c}{[\mathrm{Fe}] /} \\
\mu \mathrm{g} \mathrm{L}^{-1}\end{array}$ & $\begin{array}{c}{[\mathrm{Ni}] /} \\
\mu \mathrm{g} \mathrm{L}^{-1}\end{array}$ & $\begin{array}{l}{[\mathrm{Zn}] /} \\
\mu \mathrm{g} \mathrm{L}^{-1}\end{array}$ \\
\hline 1 & $3.9 \pm 0.3$ & $8.5 \pm 0.4$ & $<\mathrm{LOQ}$ & $<\mathrm{LOQ}$ & $202 \pm 2$ \\
\hline 2 & $3.1 \pm 0.5$ & $9.8 \pm 0.7$ & $<\mathrm{LOQ}$ & $15 \pm 6$ & $<\mathrm{LOQ}$ \\
\hline 3 & $3.4 \pm 0.1$ & $8.1 \pm 0.1$ & $38.5 \pm 0.4$ & $<\mathrm{LOQ}$ & $<$ LOQ \\
\hline 4 & $3.4 \pm 0.1$ & $8.7 \pm 0.9$ & $<\mathrm{LOQ}$ & $18.60 \pm 0.09$ & $177.0 \pm 0.4$ \\
\hline 5 & $<\mathrm{LOQ}$ & $7.5 \pm 0.1$ & $<$ LOQ & $<\mathrm{LOQ}$ & $149.2 \pm 0.7$ \\
\hline 6 & $3.1 \pm 0.3$ & $10.4 \pm 0.4$ & $23.9 \pm 0.4$ & $15.1 \pm 0.6$ & $192.3 \pm 1.4$ \\
\hline 7 & $2.9 \pm 0.3$ & $7.2 \pm 0.4$ & $33.4 \pm 0.4$ & $12.5 \pm 0.4$ & $155.8 \pm 0.2$ \\
\hline 8 & $3.1 \pm 0.1$ & $7.0 \pm 0.4$ & $30.40 \pm 0.02$ & $18.0 \pm 0.4$ & $164 \pm 2$ \\
\hline 9 & $2.1 \pm 0.9$ & $6.8 \pm 0.8$ & $25.7 \pm 1.1$ & $14 \pm 3$ & $164.5 \pm 0.6$ \\
\hline 10 & $2.0 \pm 0.6$ & $5.5 \pm 0.4$ & $30.8 \pm 0.3$ & $15.0 \pm 0.1$ & $<$ LOQ \\
\hline 11 & $<\mathrm{LOQ}$ & $6.3 \pm 0.9$ & $19.6 \pm 1.7$ & $13.6 \pm 0.1$ & $152.6 \pm 0.6$ \\
\hline 12 & $<\mathrm{LOQ}$ & $6.7 \pm 0.3$ & $16.5 \pm 0.3$ & $14.100 \pm 0.003$ & $164 \pm 2$ \\
\hline
\end{tabular}




\begin{tabular}{|c|c|c|c|c|c|}
\hline 13 & $2.4 \pm 0.6$ & $7.9 \pm 0.2$ & $30 \pm 3$ & $15.0 \pm 0.3$ & $175.9 \pm 0.8$ \\
\hline 14 & $2 \pm 1$ & $10.9 \pm 0.4$ & $27 \pm 2$ & $15.2 \pm 0.2$ & $190.9 \pm 0.9$ \\
\hline 15 & $3.4 \pm 0.4$ & $8.6 \pm 0.5$ & $27.6 \pm 0.6$ & $15.84 \pm 0.04$ & $180.7 \pm 0.9$ \\
\hline 16 & $2.7 \pm 0.4$ & $8.4 \pm 0.2$ & $40.9 \pm 0.8$ & $18.8 \pm 0.1$ & $17 \pm 1$ \\
\hline 17 & $3 \pm 1$ & $7 \pm 1.4$ & $26 \pm 4$ & $19.9 \pm 0.8$ & $176 \pm 7$ \\
\hline 18 & $2.3 \pm 0.2$ & $7.2 \pm 0.5$ & $18 \pm 1$ & $18.3 \pm 0.1$ & $197.7 \pm 0.9$ \\
\hline Mean \pm SD & $2.9 \pm 0.2$ & $7.9 \pm 0.5$ & $27.7 \pm 1.1$ & $15.9 \pm 0.8$ & $174 \pm 1$ \\
\hline LOD & 0.54 & 1.01 & 1.73 & 0.49 & 0.77 \\
\hline LOQ & 1.78 & 3.38 & 2.44 & 1.64 & 2.58 \\
\hline$\lambda(\mathrm{nm})$ & 283.5 & 324.7 & 259.9 & 231.6 & 213.8 \\
\hline
\end{tabular}

\subsubsection{Quantitative filter paper}

Table 3 reports the concentration of the metals found in the quantitative filter paper and a zinc concentration of $156 \pm 2 \mu \mathrm{g} \mathrm{L}^{-1}$. Based on these results, it was concluded that it would occur overestimation of levels in the elution step of biocides. In addition, the presence of $\mathrm{Fe}$ and $\mathrm{Ni}$ metals may contribute to (trans-) metallization with the booster antifouling biocides. Therefore, the decontaminated filter paper was used in all stages of the gravity filtration technique and especially in the elution step.

Table 3. Metal concentrations quantified in the filter paper decontamination process by ICP OES (axial view) $(n=15)$.

\begin{tabular}{|c|c|c|c|c|c|}
\hline Solution of $\mathrm{HNO}_{3}$ & $\begin{array}{l}{[\mathrm{Cr}] /} \\
\mu \mathrm{g} \mathrm{L}^{-1}\end{array}$ & $\begin{array}{l}{[\mathrm{Cu}] /} \\
\mu \mathrm{g} \mathrm{L}^{-1}\end{array}$ & $\begin{array}{c}{[\mathrm{Fe}] /} \\
\mu \mathrm{g} \mathrm{L}^{-1}\end{array}$ & $\begin{array}{c}{[\mathrm{Ni}] /} \\
\mu \mathrm{g} \mathrm{L}^{-1}\end{array}$ & $\begin{array}{l}{[\mathrm{Zn}] /} \\
\mu \mathrm{g} \mathrm{L}^{-1}\end{array}$ \\
\hline Mean \pm SD & $<\mathrm{LOQ}$ & $<\mathrm{LOQ}$ & $194 \pm 10$ & $22 \pm 3$ & $156 \pm 2$ \\
\hline LOD & 0.82 & 0.56 & 1.13 & 0.40 & 0.34 \\
\hline LOQ & 2.74 & 1.86 & 3.76 & 1.32 & 1.12 \\
\hline$\lambda(\mathrm{nm})$ & 267.7 & 324.7 & 238.2 & 221.6 & 213.8 \\
\hline
\end{tabular}

\subsubsection{Adsorption and recovery of $\mathrm{Zn}(P T)_{2}$, Zineb} and Ziram by the Si-PH sorbent in the ultrapure water fortified sample

Usually, 100-200 $\mathrm{mL}$ of water sample is used to percolate the cartridge containing silica with a flow rate above $2 \mathrm{~mL} \min ^{-1}$ by use of the manifold ${ }^{37}$. However, the developed method used only $40 \mathrm{~mL}$ of sample and the direct contact and constant stirring of the Si-PH sorbent contributed to a good adsorption of the booster antifouling biocides as showed in Tab. 4. The stock solution dissolutions of the booster antifouling biocides resulted a $\mathrm{pH}$ value of 6.5 in the ultrapure water fortified sample which is close to that found in tropical estuarine environment water ${ }^{38,39}$.

The adsorbed mass and adsorption of the booster antifouling biocides by the Si-PH sorbent in the ultrapure water fortified solution in the SPE procedure as showed in Tab. 4.

The results evidenced that $\mathrm{Zn}(\mathrm{PT})_{2}$ demonstrated good adsorption, indicating the occurrence of $\pi-\pi$ interactions between the phenyl group present in both Si-PH sorbent and $\mathrm{Zn}(\mathrm{PT})_{2}{ }^{40}$. This feature is advantageous because it allows its application in the reverse phase SPE for extraction of $\mathrm{Zn}(\mathrm{PT})_{2}$ from the estuarine water.

It is suggested that hydrophobic interactions could occur between the Si-PH sorbent and the Zineb and Ziram, once both have nonpolar groups at their endings and were eluted with methanol, which is used for the extraction of nonpolar analyte and moderately nonpolar analyte by use of reverse phase SPE technique.

Table 4. Adsorption of $\mathrm{Zn}(\mathrm{PT})_{2}$, Zineb and Ziram by the Si-PH sorbent in SPE in ultrapure water fortified with booster antifouling biocides $(n=3)$.

\begin{tabular}{|c|c|c|c|c|}
\hline Analyte & $\begin{array}{c}\text { [Zn] In. Sol. / } \\
\mu \mathrm{g} \mathrm{L}^{-1}\end{array}$ & $\begin{array}{c}\text { [Zn] Final Sol. / } \\
\mu \mathrm{g} \mathrm{L}^{-1}\end{array}$ & $\begin{array}{c}\text { Adsorbed Mass / } \\
\mu \mathrm{g}(\% \text { RSD) }\end{array}$ & Adsorption / \% \\
\hline $\mathrm{Zn}(\mathrm{PT})_{2}$ & $36.6 \pm 0.5$ & $2.11 \pm 0.05$ & $1.3 \pm 0.1(9.07)$ & $94.2 \pm 0.1$ \\
\hline Zineb & $43.3 \pm 0.3$ & $6.40 \pm 0.07$ & $1.47 \pm 0.02(1.36)$ & $85.13 \pm 0.04$ \\
\hline Ziram & $49.1 \pm 0.4$ & $3.2 \pm 0.1$ & $1.83 \pm 0.01(0.73)$ & $93.35 \pm 0.09$ \\
\hline
\end{tabular}


3.1.5 Adsorption and recovery of $\mathrm{Zn}(P T)_{2}$, Zineb and Ziram by the Si-PH sorbent in the water sample of the Santos/SP Estuary (Brazil)

The adsorbed and eluted mass and the $\%$ recovery of $\mathrm{Zn}(\mathrm{PT})_{2}$, Zineb and Ziram by the $\mathrm{Si}$-PH sorbent in the sample (Santos/SP estuary water) fortified with the booster antifouling biocides in the SPE procedure are presented in Tab. 5.

The type and volume of conditioning and elution solvent (methanol) used in SPE of booster antifouling biocides from estuarine water demonstrated good extraction efficiency (recoveries between $\sim 85 \%$ and $111 \%$ ) due to the fact that methanol is more polar than $\mathrm{Si}-\mathrm{PH}$ sorbent and used for the extraction of nonpolar analyte and moderately nonpolar analyte ${ }^{41}$. In addition, the extraction efficiency was favored by dividing the volume of $5 \mathrm{~mL}$ of methanol used in the elution into 5 times of $1 \mathrm{~mL}$.

The concentration factor obtained by the ratio of the initial sample volume $(40 \mathrm{~mL})$ to the final volume of the concentrated solution $(5 \mathrm{~mL})$ was 8 . This concentration factor was sufficient to quantify the zinc by ICP-MS in the eluate after the 20 -fold dilution.

The recovery of $\mathrm{Zn}(\mathrm{PT})_{2}$ in estuarine water $(85 \pm 2 \%)$ in the developed method is very close to that obtained by Grunnet and Dahllöf ${ }^{20}$, where they obtained $85 \%$ recovery for $\mathrm{Zn}(\mathrm{PT})_{2}$ when using cartridge Strata $X$ in the SPE technique to pre-concentrate $\mathrm{Zn}(\mathrm{PT})_{2}$ from seawater. This fact demonstrates that the use of the gravity filtration technique used in this research did not negatively influence the results obtained in the elution step.

Good recoveries for zinc pyrithione $(85 \pm 2 \%)$, Zineb $(89 \pm 5 \%)$ and Ziram $(111 \pm 2 \%)$ in the elution step for booster antifouling biocides from the fortified estuarine water were obtained. These results are in accordance with the recommendation of the US Environmental Protection Agency (EPA), because they accept to validate extraction methods with recovery in the range of $70 \%$ to $130 \%{ }^{37}$. In addition, it is emphasized that the Si-PH sorbent (phenyl-bonded) was first evaluated to adsorb the dithiocarbamates Zineb and Ziram from estuarine water.

Table 5. Zinc recovery in the Santos/SP Estuary water sample fortified with $\mathrm{Zn}(\mathrm{PT})_{2}$, Zineb and Ziram $(\mathrm{n}=3)$.

\begin{tabular}{|c|c|c|c|}
\hline Analyte & $\begin{array}{c}\text { Adsorbed Mass / } \\
\mu \mathrm{g} \pm \text { SD }(\% \text { RSD) }\end{array}$ & $\begin{array}{c}\text { Eluted Mass / } \\
\mu \mathrm{g} \pm \text { SD (\% RSD) }\end{array}$ & $\begin{array}{c}\text { Recovery / } \\
\%\end{array}$ \\
\hline $\mathrm{Zn}(\mathrm{PT})_{2}$ & $1.85 \pm 0.08(4.59)$ & $1.5 \pm 0.1(6.27)$ & $85 \pm 2$ \\
\hline Zineb & $2.43 \pm 0.08(3.49)$ & $2.1 \pm 0.1(7.78)$ & $89 \pm 5$ \\
\hline Ziram & $2.20 \pm 0.08(3.86)$ & $2.45 \pm 0.06(2.60)$ & $111 \pm 2$ \\
\hline
\end{tabular}

\subsubsection{Limit of detection and quantification}

Based on the experimental procedure for the determination of the limit of detection and quantification of the SPE method developed, the concentration of zinc obtained in the eluate (triplicate) of this procedure was $0.9 \pm 0.2 \mu \mathrm{g} \mathrm{L}^{-1}$.

Therefore, the limit of detection (LOD) of the SPE analytical method using the fortified sample of estuarine water was calculated by multiplying of the standard deviation (0.2) by 3 and the limit of quantification (LOQ) by multiplying of the standard deviation $(0.22)$ by 10 . So, the LOD and LOQ values obtained for SPE were $0.66 \mu \mathrm{g} \mathrm{L}^{-1}$ and $2.19 \mu \mathrm{g} \mathrm{L}{ }^{-1}$, respectively.

\section{Conclusions}

The metals removal procedure of the phenylbonded silica-based sorbent was efficient, once it eliminated the possibility of overestimation of the values during the determination of zinc by ICPMS and avoided the (trans-) metallization of the biocides with others metals $\mathrm{Cr}, \mathrm{Cu}, \mathrm{Fe}, \mathrm{Ni}$ present in the $\mathrm{Si}-\mathrm{PH}$ sorbent.

The results obtained in this research allow to conclude that the proposed analytical method is efficient, considering the LOD obtained of 0.66 $\mu \mathrm{g} \mathrm{L} \mathrm{L}^{-1}$.

Good recoveries were obtained between $\sim 85 \%$ and $111 \%$ in the elution step of the $\mathrm{Zn}(\mathrm{PT})_{2}$, Zineb and Ziram biocides in the SPE by zinc determination via ICP-MS from the fortified estuarine water without altering the $\mathrm{pH}$, filtering or diluting the sample in ultrapure water.

Additionally, the proposed approach it may be useful in the sample preparation step for speciation studies of the booster antifouling biocides $\mathrm{Zn}(\mathrm{PT})_{2}$, Zineb and Ziram in estuarine water, such as, in the HPLC-ICP-MS coupling 
because the proposed approach pre concentrated the sample and it eliminates the (trans-) metallization that could occur with the metals present in the evaluated sorbent.

\section{Acknowledgments}

The authors thank São Paulo Research Foundation (FAPESP grant \#2015/03397-4), Brazilian National Council for Scientific and Technological Development (CNPq grant \#164326/20154) and Coordination for the Improvement of Higher Education Personnel (CAPES) for financial support.

\section{References}

[1] Yebra, D. M., Kiil, S., Dam-Johansen, K., Antifouling technology_past, present, and future steps towards efficient and environmentally friendly antifouling coatings, Progress in Organic Coatings 50 (2) (2004) 75-104. https://doi.org/10.1016/j.porgcoat.2003.06.001.

[2] Voulvoulis, N., Scrimshaw, M. D., Lester, J. N., Analytical methods for the determination of 9 antifouling paint booster biocides in estuarine water samples, Chemosphere 38 (15) (1999) 3503-3516. https://doi.org/10.1016/S0045-6535(98)00580-3.

[3] Boxall, A. B. A., Comber, S. D., Conrad, A. U., Howcroft, J., Zaman, N., Inputs, Monitoring and Fate Modelling of Antifouling Biocides in UK Estuaries, Marine Pollution Bulletin 40 (11) (2000) 898-905. https://doi.org/10.1016/S0025-326X(00)00021-7.

[4] Thomas, K. V., The environmental fate and behaviour of antifouling paint booster biocides: A review, Biofouling $17 \quad$ (1) (2001) 73-86. https://doi.org/10.1080/08927010109378466.

[5] Almond, K. M., Trombetta, L. D., The effects of copper pyrithione, an antifouling agent, on developing zebrafish embryos, Ecotoxicology 25 (2) (2016) 389398. https://doi.org/10.1007/s10646-015-1597-3.

[6] Amara, I., Miled, W., Slama, R. B., Ladhari, N., Antifouling processes and toxicity effects of antifouling paints on marine environment. A review, Environmental Toxicology and Pharmacology 57 (2018) 115-130. https://doi.org/10.1016/j.etap.2017.12.001.

[7] Kobayashi, N., Okamura, H., Effects of new antifouling compounds on the development of sea urchin, Marine Pollution Bulletin 44 (8) (2002) 748 751. https://doi.org/10.1016/S0025-326X(02)00052-8.

[8] Cima, F., Ballarin, L., Immunotoxicity in ascidians: Antifouling compounds alternative to organotins-IV. The case of zinc pyrithione, Comparative Biochemistry and Physiology Part C: Toxicology \& Pharmacology 169 (2015) 16-24. https://doi.org/10.1016/j.cbpc.2014.12.007.

[9] Dallas, L. J., Turner, A., Bean, T. P., Lyons, B. P., Jha, A. N., An integrated approach to assess the impacts of zinc pyrithione at different levels of biological organization in marine mussels, $\begin{array}{llll}\text { Chemosphere } & 196 & \text { (2018) } & \text { 531-539. }\end{array}$ https://doi.org/10.1016/j.chemosphere.2017.12.144.

[10] Ren, T., Fu, G.-H., Liu, T.-F., Hu, K.; Li, H.-R., Fang, W.-H., Yang, X.-L., Toxicity and accumulation of zinc pyrithione in the liver and kidneys of Carassius auratus gibelio: association with $\mathrm{P}$-glycoprotein expression, Fish Physiology and Biochemistry 43 (1) (2017) 1-9. https://doi.org/10.1007/s10695-016-0262y.

[11] Jung, S. M., Bae, J. S., Kang, S. G., Son, J. S., Jeon, J. H., Lee, H. J., Jeon, J. Y., Sidharthan, M., Ryu, S. H., Shin, H. W., Acute toxicity of organic antifouling biocides to phytoplankton Nitzschia pungens and zooplankton Artemia larvae, Marine Pollution Bulletin 124 (2) (2017) 811-818. https://doi.org/10.1016/j.marpolbul.2016.11.047.

[12] Doose, C. A., Szaleniec, M., Behrend, P., Müller, A., Jastorff, B., Chromatographic behavior of pyrithiones, Journal of Chromatography A 1052 (1-2) (2004)

103-110.

https://doi.org/10.1016/j.chroma.2004.08.028

[13] Hercegová, A., Dömötörová, M., Matisová, E., Sample preparation methods in the analysis of pesticide residues in baby food with subsequent chromatographic determination, Journal of Chromatography A $1153 \quad(1-2) \quad$ (2007) 54-73. https://doi.org/10.1016/j.chroma.2007.01.008.

[14] Chen, Y., Guo, Z., Wang, X., Qiu, C., Sample preparation, Journal of Chromatography A 1184 (1-2) (2008)

191-219. https://doi.org/10.1016/j.chroma.2007.10.026

[15] Andrade-Eiroa, A., Canle, M., Leroy-Cancellieri, V., Cerdà, V., Solid-phase extraction of organic compounds: A critical review (Part I), TrAC Trends in Analytical Chemistry $80 \quad$ (2016) 641-654. https://doi.org/10.1016/j.trac.2015.08.015. 
[16] Andrade-Eiroa, A., Canle, M., Leroy-Cancellieri, V., Cerdà, V., Solid-phase extraction of organic compounds: A critical review. part ii, TrAC Trends in $\begin{array}{llll}\text { Analytical Chemistry } 80 & \text { (2016) 655-667. }\end{array}$ https://doi.org/10.1016/j.trac.2015.08.014.

[17] Weissmahr, K. W., Houghton, C. L., Sedlak, D. L., Analysis of the Dithiocarbamate Fungicides Ziram, Maneb, and Zineb and the Flotation Agent Ethylxanthogenate by Ion-Pair Reversed-Phase HPLC, Analytical Chemistry 70 (22) (1998) 4800-4804. https://doi.org/10.1021/ac980626w.

[18] Bones, J., Thomas, K. V., Paull, B., Improved method for the determination of zinc pyrithione in environmental water samples incorporating on-line extraction and preconcentration coupled with liquid chromatography atmospheric pressure chemical ionisation mass spectrometry, Journal of Chromatography A 1132 (1-2) (2006) 157-164. https://doi.org/10.1016/j.chroma.2006.07.068.

[19] Malik, A. K., Sharma, V., Sharma, V. K., Rao, A. L. J., Column Preconcentration and Spectrophotometric Determination of Ziram and Zineb in Commercial Samples and Foodstuffs Using (1,2‘Pyridylazo)-2-naphthol (PAN)-Naphthalene as Adsorbate, Journal of Agricultural and Food Chemistry $52 \quad$ (26) (2004) 7763-7767. https://doi.org/10.1021/jf040326h.

[20] Grunnet, K. S., Dahllof, I., Environmental fate of the antifouling compound zinc pyrithione in seawater, Environmental Toxicology and Chemistry 24 (12) (2005) 3001-3006. https://doi.org/10.1897/04-627R.1.

[21] Bajia, S., Ojha, K. G., Synthesis, separation and determination of metal dithiocarbamates complexes by HPLC-ICP-MS, Eurasian Journal of Analytical $\begin{array}{llll}\text { Chemistry } & 8 & \text { (3) (2013) 107-111. }\end{array}$ http://www.eurasianjournals.com/Synthesis-

Separation-and-Determination-of-Metal-

Dithiocarbamates-Complexes-by-

HPLC, 79714,0,2.html.

[22] Sakkas, V. A., Shibata, K., Yamaguchi, Y., Sugasawa, S., Albanis, T., Aqueous phototransformation of zinc pyrithione: Degradation kinetics and byproduct identification by liquid chromatography-atmospheric pressure chemical ionisation mass spectrometry, Journal of Chromatography A 1144 (2) (2007) 175-182. https://doi.org/10.1016/j.chroma.2007.01.049.

[23] Ahmadi, F., Rajabi, M., Faizi, F., RahimiNasrabadi, M., Maddah, B., Magnetic solid-phase extraction of Zineb by C18-functionalised paramagnetic nanoparticles and determination by first- derivative spectrophotometry, International Journal of Environmental Analytical Chemistry 94 (11) (2014) 1123-1138.

https://doi.org/10.1080/03067319.2014.940339.

[24] Hashemi, F., Rastegarzadeh, S., Pourreza, N., A combination of dispersive liquid-liquid microextraction and surface plasmon resonance sensing of gold nanoparticles for the determination of ziram pesticide, Journal of Separation Science 41 (5) (2018) 1156-1163. https://doi.org/10.1002/jssc.201700992.

[25] Thomas, K. V., Determination of the antifouling agent zinc pyrithione in water samples by copper chelate formation and high-performance liquid chromatography-atmospheric pressure chemical ionisation mass spectrometry, Journal of Chromatography A 833 (1) (1999) 105-109. https://doi.org/10.1016/S0021-9673(98)01009-7.

[26] Harino, H., Midorikawa, S., Arai, T., Ohji, M., $\mathrm{Cu}$, N. D., Miyazaki, N., Concentrations of booster biocides in sediment and clams from Vietnam, Journal of the Marine Biological Association of the United Kingdom $86 \quad$ (5) (2006) 1163-1170. https://doi.org/10.1017/S0025315406014147.

[27] Kim, T. H., Jung, G. H., Lee, E. H., Park, H. R., Lee, J. K., Kim, H. G., Development and validation of liquid chromatography-tandem mass spectrometry method for simultaneous determination of zinc pyrithione and pyrithione in shampoos, Acta

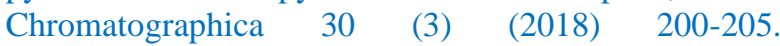
https://doi.org/10.1556/1326.2017.00294.

[28] Lo, C.-C., Ho, M.-H., Hung, M.-D., Use of HighPerformance Liquid Chromatographic and Atomic Absorption Methods To Distinguish Propineb, Zineb, Maneb, and Mancozeb Fungicides, Journal of Agricultural and Food Chemistry 44 (9) (1996) 27202723. https://doi.org/10.1021/jf9600081.

[29] Kondoh, Y., Takano, S., Determination of zinc pyrithione in cosmetic products by high-performance liquid chromatography with pre-labelling, Journal of Chromatography A $408 \quad$ (1987) 255-262. https://doi.org/10.1016/S0021-9673(01)81808-2.

[30] Agarwal, S., Aggarwal, S. G., Singh, P., Quantification of ziram and zineb residues in fog-water samples, Talanta 65 (1) (2005) 104-110. https://doi.org/10.1016/j.talanta.2004.05.041.

[31] Kumar, P., Ahlawat, S., Chauhan, R., Kumar, A., Singh, R., Kumar, A., In vitro and field efficacy of fungicides against sheath blight of rice and post-harvest fungicide residue in soil, husk, and brown rice using gas chromatography-tandem mass spectrometry, 
Environmental Monitoring and Assessment 190 (9) (2018) 503. https://doi.org/10.1007/s10661-018-68977.

[32] U.S. EPA, Method 6020B (SW-846): Inductively Coupled Plasma-Mass Spectrometry, Revision 2. Washington, 2014. https://www.epa.gov/esam/epamethod-6020b-sw-846-inductively-coupled-plasmamass-spectrometry.

[33] Hu, Z., Hu, S., Gao, S., Liu, Y., Lin, S., Volatile organic solvent-induced signal enhancements in inductively coupled plasma-mass spectrometry: a case study of methanol and acetone, Spectrochimica Acta Part B: Atomic Spectroscopy 59 (9) (2004) 1463-1470. https://doi.org/10.1016/j.sab.2004.07.007.

[34] Currie, L. A., Nomenclature in evaluation of analytical methods including detection and quantification capabilities, Pure and Applied Chemistry $67 \quad$ (10) 1699-1723. https://doi.org/10.1351/pac199567101699.

[35] Phenomenex, Sample preparation - made simple selection and users guide, Phenomenex: Torrance, 2015.

http://phx.phenomenex.com/lib/BR27941114_W.pdf.

[36] Nováková, L., Vlčková, H., A review of current trends and advances in modern bio-analytical methods: Chromatography and sample preparation, Analytica

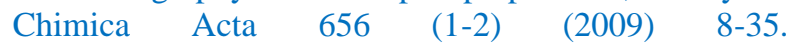
https://doi.org/10.1016/j.aca.2009.10.004.

[37] Hennion, M.-C., Solid-phase extraction: method development, sorbents, and coupling with liquid chromatography, Journal of Chromatography A 856 (12) (1999) 3-54. https://doi.org/10.1016/S00219673(99)00832-8.

[38] Araújo, D., Machado, W., Weiss, D., Mulholland, D. S., Boaventura, G. R., Viers, J., Garnier, J., Dantas, E. L., Babinski, M., A critical examination of the possible application of zinc stable isotope ratios in bivalve mollusks and suspended particulate matter to trace zinc pollution in a tropical estuary, Environmental Pollution $226 \quad$ (2017) 41-47. https://doi.org/10.1016/j.envpol.2017.04.011.

[39] Milazzo, A. D. D., Silva, A. C. M., Oliveira, D. A. F., Cruz, M. J. M., The influence of seasonality (dry and rainy) on the bioavailability and bioconcentration of metals in an estuarine zone, Estuarine, Coastal and Shelf Science $149 \quad$ (2014) 143-150. https://doi.org/10.1016/j.ecss.2014.08.013.

[40] Vallet-Regí, M., Izquierdo-Barba, I., Colilla, M., Structure and functionalization of mesoporous bioceramics for bone tissue regeneration and local drug delivery, Philosophical Transactions of the Royal Society A: Mathematical, Physical and Engineering Sciences $370 \quad$ (1963) (2012) 1400-1421. https://doi.org/10.1098/rsta.2011.0258.

[41] Sigma-Aldrich Co., Guide to Solid Phase Extraction, Bulletin 1998. https://www.sigmaaldrich.com/Graphics/Supelco/objec ts/4600/4538.pdf. 